\title{
MENINGKATKAN SUPERVISI AKADEMIK SEORANG GURU DALAM MEWUJUDKAN PROFESONALISME GURU
}

\author{
Reza Ahmad Kurniawan \\ Email: 2010128210013 @mhs.ulm.ac.id \\ Program Studi Pendidikan IPS Fakultas Keguruan dan Ilmu Pendidikan \\ Universitas Lambung Mangkurat
}

Banjarmasin

\begin{abstract}
Abstrak
Profesi guru diselenggarakan melalui pengembangan diri yang dilakukan secara demokratis, berkeadilan, tidak diskriminatif, dan berkelanjutan dengan menjunjung tinggi hak asasi manusia, nilai keagamaan, nilai kultural, kemajemukan bangsa, dan kode etik profesi. Salah satu program yang dapat diselenggarakan dalam rangka pemberdayaan guru adalah supervisi akademik. Supervisi akademik merupakan upaya membantu guru-guru mengembangkan kemampuannya mencapai tujuan pembelajaran. Dengan demikian, berarti, esensi supervisi akademik itu sama sekali bukan menilai unjuk kerja guru dalam mengelola proses pembelajaran, melainkan membantu guru mengembangkan kemampuan profesionalismenya. Guru akan bekerja secara professional apabila ia memiliki kompetensi yang memadai. Maksudnya adalah seorang guru akan bekerja secara profesional apabila ia memiliki kompetensi secara utuh. Seseorang tidak akan bisa bekerja secara profesional apabila ia hanya memenuhi salah satu kompetensi di antara sekian kompetensi yang dipersyaratkan.
\end{abstract}

Pendahuluan

Esensi sebuah pendidikan persekolahan adalah proses pembelajaran. Tidak ada kualitas pendidikan persekolahan tanpa kualitas pembelajaran. Berbagai upaya peningkatan mutu pendidikan persekolahan dapat dianggap kurang berguna bilamana belum menyentuh perbaikan proses pembelajaran. Oleh karena itu dalam rangka peningkatan kualitas pendidikan persekolahan Pemerintah, dalam hal ini Kementerian Pendidikan Nasional, mengembangkan berbagai program yang diharapkan dapat meningkatkan kualitas pembelajaran. Di antara keseluruhan komponen dalam pemblajaran guru merupakan komponen organik yang sangat menentukan. Tidak ada kualitas pembelajaran tanpa kualitas guru. Apapun yang telah dilakukan oleh Pemerintah, namun yang pasti adalah peningkatan 
kualitas pembelajaran tidak mungkin ada tanpa kualitas kinerja guru, sehingga peningkatan kualitas pembelajaran, juga tidaklah mungkin ada tanpa peningkatan kualitas para gurunya. Guru merupakan sumber daya manusia yang sangat menentukan keberhasilan pembelajaran. Guru merupakan unsur pendidikan yang sangat dekat hubungannya dengan anak didik dalam upaya pendidikan sehari-hari di sekolah dan banyak menentukan keberhasilan anak didik dalam mencapai tujuan. Begitu sangat strategisnya kedudukan guru sebagai tenaga profesional, di dalam program yang dapat diselenggarakan dalam rangka pemberdayaan guru adalah supervisi akademik.

Menurut Manullang (2005:179), "Supervisi akademik adalah serangkaian kegiatan membantu guru mengembangkan kemampuannya mengelola proses pembelajaran demi pencapaian tujuan akademik". Supervisi akademik merupakan upaya membantu guru-guru mengembangkan kemampuannya mencapai tujuan akademik. Dengan demikian, berarti, esensial supervisi akademik adalah membantu guru mengembangkan kemampuan profesionalismenya.

Mengembangkan kemampuan dalam konteks ini janganlah ditafsirkan secara sempit, sematamata ditekankan pada peningkatan pengetahuan dan keterampilan mengajar guru, melainkan juga pada peningkatan komitmen, kemauan atau motivasi guru, sebab dengan meningkatkan kemampuan dan motivasi kerja guru, kualitas akademik akan meningkat.

Semua ini merupakan prinsip-prinsip supervisi akademik modern yang harus direalisasikan pada setiap proses supervisi akademik di sekolah-sekolah. Menurut Dharma (2008:13) mengemukakan bahwa ada beberapa prinsip lain yang harus diperhatikan dan direalisasikan oleh supervisor dalam melaksanakan supervisi akademik, yaitu:

A. Supervisi akademik harus mampu menciptakan hubungan kemanusiaan yang harmonis.

B. Supervisi akademik harus dilakukan secara berkesinambungan. Supervisi akademik bukan tugas bersifat sambilan yang hanya dilakukan sewaktu-waktu jika ada kesempatan.

C. Supervisi akademik harus demokratis. Supervisor tidak boleh mendominasi pelaksanaan supervisi akademiknya.

D. Program supervisi akademik harus integral dengan program pendidikan. Di dalam setiap organisasi pendidikan terdapat bermacam-macam sistem perilaku dengan tujuan sama, yaitu tujuan pendidikan.

E. Supervisi akademik harus komprehensif. Program supervise akademik harus mencakup keseluruhan aspek pengembangan akademik, walaupun mungkin saja ada penekanan pada aspek-aspek tertentu berdasarkan hasil analisis kebutuhan pengembangan akademik sebelumnya.

F. Supervisi akademik harus objektif. Dalam menyusun, melaksanakan, dan mengevaluasi, keberhasilan program supervisi akademik harus objektif.

Bahri, S. (2014). Supervisi akademik dalam peningkatan profesionalisme guru. Visipena, 5(1), 100-112. 


\section{PERAN GURU SEBAGAI SEBUAH PROFESI}

Guru adalah jabatan profesional yang memilik tugas pokok yang amat menentukan dalam proses pertumbuhan dan perkembangan peserta didik. Uraian tugas pokok tersebut mencakup keseluruhan unsur yang terlibat dan berperan dalam proses pembelajaran. Tugas pokok itu hanya dapat dilaksanakan secara profesional bila persyaratan-persyaratan sebaga guru terpenuhi. Adapun persyaratan profesional seorang guru sebagai berikut:

1. Memiliki kualifikasi pendidikan sekurang-kurangnya pada jenjang Diploma atau Sarjana Pendidikan yang didalamnya tercantum dengan jelas akta kewenangan mengajar.

2. Memilik ciri ciri kepribadian sebagi seorang pendidik seperti memiliki kasih sayang yang tulus kepada peserta didik, memiliki komitmen untuk ikut membantu pertumbuhan peserta didik secara utuh dan sempurna, jujur, ikhlas, adil bijaksana, dan penolong serta menjunjung hak-hak asasi manusia.

3. Menghargai perbedaan-perbedaan secara kultural, sosial dan spiritual.

4. Menjunjung tinggi nilai nilai budaya yang menjadi acuan masyarakat dalam hidupnnya.

5. Diterima dan diakui oleh masyarakat sebagai guru dan pendidik.

6. Guru harus berahlak mulia dan menjadi contoh teladan baik bagi peserta didik, maupun bagi masyarakat banyak.

tugas pokok guru adalah sebaga beiikut:

1. Membantu peserta didik untuk mengembangkan seluruh potensinnya sehingga tumbuh dan berkembang dengan total dan sempurna.

2. Membantu peserta didik agar potensi itelektual, emosional dan spritualnya tumbuh berkembang secara seimbang dan harmonis serta sempurna.

3. Mentransformasikan berbagai ilmu pengetahuan kepada peserta didik dengan menggunakan pendekatan dan metodologi yang penuh keatifitas dalam proses belajar mengajar, sehinga khasanah ilmu pengetahuan dan kreatifitas peserta didik tumbuh dan berkembang pula.

4. Menanamkan nilai-nilai positif yang diperlukan dalam hidup kedalam diri peserta didik sehingga melekat dan tumbuh menjadi satu dengan prilaku peserta didik.

5. Membangun watak dan kepribadian peserta didik menjadi orang yang memiliki watak dan kepribadian utuh dan sempurna.

6. Membantu mengembangkan kemampuan peserta didik dalam menjalankan fungsinnya sebagai makhluk sosial yang beradab dan bermartabat.

7. Menumbuhkembangkan dalam diri peserta didik nilai-nilai perilaku mulia.

8. Memberikan tuntunan kepada peserta didik untuk mengenal mana perbuatan, yang baik dan yang tidak, mana perbuatan yang dilarang mana pula yang tidak dilarang. 
Gaffar, M. F. (2017). Guru Sebagai Profesi. Jurnal Administrasi Pendidikan, 5(1).

\section{GURU INDONESIADAN TANTANGAN PROFESIONALISME}

Transformasi kehidupan berbangsa melalui jalur pendidikan tidak dapat dilepaskan dari peran guru. Guru-guru adalah ujung tombak dalam menghasilkan pribadi-pribadi yang berkualitas dan kompetitif. Oleh karena itu, mereka memiliki peran yang sangat vital dalam meningkatkan kualitas anak didiknya. Mereka adalah aktor-aktor perubahan yang diharapkan dapat meningkatkan kualitas SDM Indonesia.

Tantangan besar dunia pendidikan adalah bagaimana mempersiapkan para peserta didik yang dapat bersaing di era kompetisi regional. Tampak sulit dan membutuhkan energi ekstra untuk melaju sesuai impian ketika kita melihat realitas dunia pendidikan masih dicederai rupa-rupa persoalan seperti kompetensi para pendidik yang rendah, sindrom mismanagement, landasan filosofis yang tambal sulam, manajemen yang rapuh, dan pergantian kurikulum yang fluktuatif. Guru sendiri sebagai aktor perubahan sedang mengalami masalah berat. Dari data yang diperoleh dapat dilihat setidaknya ada dua persoalan serius guru Indonesia sekarang ini. Kedua persoalan itu adalah profesionalisme yang masih rendah dan kompetensi guru yang memprihatinkan. Jika guru memiliki pengaruh besar terhadap prestasi siswa, maka tidak mengherankan jika prestasi anak Indonesia dalam kompetisi internasional seperti PISA sangat buruk. Artinya kedua masalah tersebut diasumsikan berpengaruh langsung terhadap kualitas SDM Indonesia.

masalah profesionalisme guru. Hingga tahun 2015, hampir semua guru di Indonesia tersertifikasi (Kemdikbud, 2015). Kendatipun demikian sertifikasi guru belum berdampak pada peningkatan mutu pendidikan di Indonesia. Penelitian yang dilakukan oleh Ditjen PMPTK (Peningkatan Mutu Pendidik dan Tenaga Kependidikan) sebagaimana dikutip Payong (2011: 89) setidaknya menemukan tiga hal yang menarik perhatian. 1) Sertifikasi belum membawa dampak terhadap peningkatan profesionalisme guru, kecuali peningkatan kesejahteraan. $76 \%$ dana tunjangan profesi dimanfaatkan untuk memenuhi kebutuhan rumah tangga guru. 2) Sertifikasi juga belum berdampak pada peningkatan penghargaan terhadap status guru sebagai profesi yang dapat dibanggakan guru itu sendiri. Ada $24 \%$ guru yang ingin menyambung hidup sebagai guru dengan mencari pekerjaan alternatif menjadi guru privat, $20 \%$ guru yang berwirausaha, dan $38 \%$ menjadi petani. 3) Sertifikasi guru belum berdampak pada peningkatan disiplin guru dalam menjalankan tugas profesinya. $45 \%$ guru tersertifikasi sering tidak masuk sekolah. Ketiga temuan tersebut memperlihatkan ketidakefektifan program sertifikasi guru yang telah dilakukan melalui penilaian portofolio dan PLPG. Selain itu, disinyalir bahwa pemberian sertifikat pendidik profesional tidak melalui assessment yang autentik dan objektif. Dana tunjangan sertifikasi guru selama ini mestinya tidak lebih dari penghargaan atas 
pengabdian guru selama belasan atau puluhan tahun, bukan tunjangan dengan fungsi menopang guru dalam menjalankan tugas profesionalnya.

kompetensi guru juga menjadi masalah yang amat serius. Data hasil UKG tahun 2015 menunjukkan rendahnya kemampuan guru Indonesia, setidaknya dilihat dari kompetensi pedagogik dan profesional. Kompetensi pedagogik menunjuk pada kemampuan guru melaksanakan pembelajaran berbasis pemahaman karakteristik siswa, penguasaan metodologi pembelajaran, dan filosofi pendidikan yang sedang dianut dalam suatu sistem pendidikan. Kompetensi profesional berkaitan dengan penguasaan bidang keahlian yang diajarkan, yakni penguasaan materi pelajaran, pemahaman ontologi, epistemologi, dan aksiologi bidang ilmu yang didalami. Hasil UKG tahun 2015 memperlihatkan nilai ratarata yang diperoleh secara nasional adalah 53,02. Perolehan ini berada di bawah standar yang ditetapkan, yakni rata-rata 55 untuk kompetensi pedagogik dan profesional. Bahkan ratarata untuk kompetensi pedagogik lebih rendah lagi, yakni 48,94 (Kemdikbud, 2016).

Chatib (2011: xviii) menyatakan bahwa ada tiga kekuatan utama guru dalam pembelajaran, yakni paradigma, cara, dan komitmen. Paradigma merupakan sudut pandang atau konsepsi yang berisi asumsiasumsi teoritik dan mendasari pelaksanaan pembelajaran. Cara menunjuk pada metode-metode atau teknik-teknik yang digunakan guru dalam pembelajaran. Sedangkan komitmen merupakan sikap dan ketetapan hati untuk menjalankan tugas profesi secara konsisten. Ketiga kekuatan inilah yang dikembangkan bersamaan dengan pengembangan kompetensi profesional guru.

Peningkatan profesionalisme guru berorientasi pada pengembangan keprofesian berkelanjutan. Pengembangan keprofesian berkelanjutan merupakan arah pengembangan profesi guru yang dipandang tepat. Pengembangan tidak dilakukan secara insidental, melainkan secara kontinyu dan variatif. Menurut Masyhud (2012: 23), pengembangan keprofesian guru berkelanjutan bertujuan untuk: 1) meningkatkan kompetensi guru, 2) memutakhirkan kompetensi guru, 3) meningkatkan komitmen guru, 4) menumbuhkan rasa cinta terhadap profesi guru, dan 5) meningkatkan citra, harkat, dan martabat guru di masyarakat.

Menurut Day (Payong, 2011: 19), pengembangan profesional berkelanjutan terdiri dari semua pengalaman belajar alamiah dan kegiatan yang sengaja direncanakan untuk memberikan manfaat langsung kepada guru-guru maupun kualitas pembelajaran di kelas. Secara individu pengembangan keprofesian berkelanjutan dilakukan melalui inisiatif guru sendiri dengan melakukan refleksi dan PTK, membaca jurnal-jurnal ilmiah, memperluas jaringan kerja, meningkatkan koleksi perpustakaan pribadi. Sebaliknya, pengembangan keprofesian berkelanjutan dapat pula dilakukan oleh kepala sekolah melalui programprogram sekolah seperti training day, kunjungan ke sekolah lain, atau mengundang narasumber dari sekolah atau instansi lain. Kolaborasi dengan guru lain pun dapat dilakukan melalui team teaching, analisis masalah bersama guru lain, bedah artikel bersama, dan lesson study.

Edu, A., Arifin, F., \& Nardi, M. (2017). Etika dan tantangan Profesionalisme Guru. 
Bahri, S. (2014). Supervisi akademik dalam peningkatan profesionalisme guru. Visipena, 5(1), 100-112.

\section{Kesimpulan}

Supervisi akademik merupakan upaya membantu guru-guru mengembangkan kemampuannya mencapai tujuan pembelajaran. Dengan demikian, berarti, esensi supervisi akademik itu sama sekali bukan menilai unjuk kerja guru dalam mengelola proses pembelajaran, melainkan membantu guru mengembangkan kemampuan profesionalismenya.

Guru akan bekerja secara professional apabila ia memiliki kompetensi yang memadai. Maksudnya adalah seorang guru akan bekerja secara profesional apabila ia memiliki kompetensi secara utuh. Seseorang tidak akan bisa bekerja secara profesional apabila ia hanya memenuhi salah satu kompetensi di antara sekian kompetensi yang dipersyaratkan. Kompetensi tersebut merupakan perpaduan antara kemampuan dan motivasi.

\section{Referensi}

Efendi, I., Prawitasari, M., \& Susanto, H. (2021). Implementasi Penilaian Pembelajaran Pada Kurikulum 2013 Mata Pelajaran Sejarah. Prabayaksa: Journal of History Education, 1(1), 21-25.

Susanto, H. (2020). Profesi Keguruan. Banjarmasin: FKIP Universitas Lambung Mangkurat.

Susanto, H., \& Akmal, H. (2018). Efektivitas Penggunaan Aplikasi Pembelajaran Berbasis Mobile Smartphone Sebagai Media Pengenalan Sejarah Lokal Masa Revolusi Fisik Di Kalimantan Selatan Pada Siswa Sekolah Menengah Atas. HISTORIA: Jurnal Program Studi Pendidikan Sejarah, 6(2), 197-206.

Susanto, H., Irmawati, I., Akmal, H., \& Abbas, E. W. (2021). Media Film Dokumenter Masuknya Islam Ke Nusantara dan Pengaruhnya Terhadap Keterampilan Berpikir Kritis Siswa. HISTORIA: Jurnal Program Studi Pendidikan Sejarah, 9(1).

Syaharuddin, S., \& Susanto, H. (2019). Sejarah Pendidikan Indonesia (Era Pra Kolonialisme Nusantara sampai Reformasi). Banjarmasin: FKIP Universitas Lambung Mangkurat. 